\title{
Paradoks universalitas HAM Barat di muka cermin Islam perspektif filsafat hukum dan HAM
}

\author{
Robby Habiba Abror \\ Jurusan Aqidah dan Filsafat, UIN Sunan Kalijaga, Yogyakarta \\ E-mail:robby_abror23@yahoo.com
}

This paper aims at examining the paradox of universality of human rights and trying to bring Western concepts of universality in the context of Islam. Human rights birth of natural philosophy which starts from Newtonian physics, then processed in the philosophy of Locke and Rousseau. So the human rights birth is indeed an effort to combat all forms of oppression by men over other men. Human rights is a concept that start with the state of human nature and hence it is universal. The state of nature in Western philosophy that was later named to the nature of Islam. Violation of human rights is a denial of the concept of universality, so that the West and Islam are required to align rational understanding and cultural particularity of the importance of human rights in the name of justice and humanity. This paper uses philosophy of law and human rights perspective as a method based on the thinking of Western philosophers and to compare with Muslim intellectuals such as Al-Jabiri, Hassan Hanafi and Maududi who had been instrumental in laying a rational approach to human rights in the Islamic theoretical framework. This paper produces an important finding that the concepts of human rights raised by Western philosophers actually been explained clearly in the Quran and hadith, so the universality of Western human rights is no longer a problem for, and can do with scientific interconnectivity, (particularity law) Islam.

Artikel ini bertujuan untuk mengkritisi paradoks universalitas HAM Barat dan berusaha untuk mendekatkan konsep universalitas tersebut dalam konteks Islam. HAM lahir dari filsafat alamiah yang dimulai dari fisika Newton, kemudian diolah dalam filsafat Locke dan Rousseau. Sehingga HAM lahir sesungguhnya merupakan upaya untuk melawan segala bentuk penindasan oleh manusia atas manusia lainnya. HAM adalah konsep yang bertitik tolak pada hakikat alamiah manusia dan karenanya ia bersifat universal. Hakikat alamiah dalam filsafat Barat itulah yang kemudian dinamakan dengan fitrah dalam Islam. Pelanggaran HAM merupakan pengingkaran terhadap konsep universalitas, sehingga Barat maupun Islam dituntut untuk dapat menyelaraskan pemahaman rasional dan partikularitas budaya 
tentang pentingnya penegakan HAM atas nama keadilan dan kemanusiaan. Artikel ini menggunakan perspektif filsafat hukum dan HAM sebagai metode dengan mendasarkan pada pemikiran para filsuf Barat dan mengkomparasikan dengan para intelektual Muslim seperti al-Jabiri, Hassan Hanafi dan Maududi yang telah berjasa dalam meletakkan pendekatan rasional atas HAM dalam kerangka teoretis Islam. Tulisan ini menghasilkan sebuah temuan penting bahwa konsep-konsep HAM yang diangkat oleh para filsuf Barat sesungguhnya telah diterangkan secara jelas dalam al-Qur'an maupun hadis, sehingga universalitas HAM Barat tidak lagi menjadi masalah bagi, dan dapat melakukan interkoneksitas keilmuan dengan, (partikularitas hukum) Islam.

Keywords: Human rights; Law; State of nature; Social contract

\section{Pendahuluan}

Inilah sebuah paradoks yang terus menghimpit manusia dari abad ke abad, tak terkecuali di abad ini, ketika demokrasi dielu-elukan dan gencar diteriakkan di muka bumi, seperti sebuah harapan bahwa manusia dilahirkan bebas, namun kenyataannya di mana-mana ia terbelenggu. Dari berabad-abad yang lampau, martabat manusia, marwah kehidupan, senantiasa dipertaruhkan. Cita-cita agung, perjuangan tentang perlindungan Hak-hak Asasi Manusia (HAM) yang didengung-dengungkan, setidaknya sejak abad ke-18 itu, tidak jarang menuai kegagalan demi kegagalan yang kerapkali memilukan. Tetapi pertengahan abad ke-18, bagaimanapun adalah momentum yang layak dikenang dalam sejarah dunia. Sekaligus harus diingat jika jauh sebelum abad itu—ide tentang hukum alam, hak dan kewajiban serta tentang martabat manusia—sudah digulirkan dan dalam sekian hal telah diterapkan.

Tragedi, tirani, darah yang tumpah akibat konflik dan peperangan, tubuh-tubuh kuli (buruh) yang dijarah dan diperas, perempuan-perempuan yang dinistakan, suara-suara yang dibungkam, martabat yang diinjak-injak, begitu banyak dijumpai di Barat maupun di negaranegara mayoritas pemeluk agama Islam. Kedua poros ini pun sering terlibat permusuhan dan benturan peradaban sepanjang sejarahnya.

Al-Jabiri mengingatkan tentang bagaimana Barat menggunakan senjata HAM melawan Uni Soviet sebelum yang terakhir runtuh, dan juga dalam menghadapi negara-negara yang membentuk apa yang disebut sebagai “Kamp Komunis", bahkan dalam melawan semua negara yang menerapkan politik dan orientasi yang tidak sejalan dengan kepentingankepentingan Barat. Sementara itu, media Barat selalu diam tentang pelanggaran HAM di berbagai negara yang dilakukan secara sengaja, terang-terangan, dan berulang kali hingga 
seolah pelanggaran HAM merupakan salah satu ketetapan politik negara tersebut, seperti pelanggaran HAM setiap hari yang terjadi di wilayah pendudukan Palestina oleh aparat negara Israel, sipil atau militer, juga yang terjadi di Afrika Selatan dan berbagai diktator sekutu dan pelayan Barat di dunia ketiga. Demikian juga pembantaian yang pernah terjadi di Bosnia Herzegovina, bahkan yang terjadi di negara-negara Eropa sendiri dimana kolonikoloni imigran, khususnya mereka yang berafiliasi dengan "Selatan", menghadapi berbagai macam tekanan, kesulitan dan diskriminasi ras (al-Jabiri, 2003: 97-98).

Apa yang diuraikan al-Jabiri itu meneguhkan kenyataan pahit di mana-mana bahwa praktekpraktek diskriminasi, eksploitasi, dan dominasi tak pernah sungguh-sungguh terhapus, baik yang bertudung kekuasaan, atau bahkan atas nama agama dan kemanusiaan, bahkan sesudah Perserikatan Bangsa-bangsa (PBB) mengemukakan Deklarasi HAM Sedunia. Tragedi BosniaHerzegovina, Rwanda, Perang Teluk, hingga stigma terorisme yang mendiskreditkan Islam terus terjadi. Dominasi Utara terhadap perekonomian global, dominasi sains Barat, dan hegemoni media Barat. Sementara dunia belahan Timur, dipandang sarat dengan fanatisme, fundamentalisme dan radikalisme agama, subordinasi perempuan, dan berbagai pelanggaran HAM lainnya.

Gelombang pesimisme menjadi sulit terhindarkan. Falk (2007: 27) dengan tegas mengkritik Barat yang tidak dapat memperbandingkan kotak "universalitasnya" dalam lingkaran "legitimasi dan otentisitas budaya", sehingga paradigma HAM Barat harus memperhatikan berbagai budaya dan tradisi keagamaan yang berbeda. Tidak ada yang menjamin bahwa situasi dunia sekarang adalah jauh lebih baik ketimbang situasi pada abad-abad yang lampau, selama "hukum internasional" belum dapat terintegrasi dengan "hukum agama". Richard Falk, Mahathir Mohammad, Anwar Ibrahim dan puluhan pemikir dunia lainnya mencurahkan kritik dan gagasan mereka dalam Human's Wrong (2007), salah satu buku yang mencoba menantang sejauhmana HAM benar-benar dijunjung terutama oleh Barat di mana Islam dan hampir seluruh bumi belahan Timur menjadi korbannya. Dalam buku itu, Fun Yew Teng mengupas habis rapor merah Barat tentang HAM, mulai dari pembantaian modern di kawasan Pasifik, Asia, Afrika, Timur Tengah, Amerika Latin. Ia mengutip pernyataan Stephen E. Ambrose yang menegaskan bahwa AS adalah sebuah negara yang "hadir karena perang, memperoleh wilayah yang besar karena perang, 
mendirikan revolusi industrinya dan kesatuan nasionalnya lewat suatu perang sipil berdarah dan memenangkan suatu koloni lewat perang" (Teng, 2007: 91).

Fenomena pelanggaran HAM yang sering dilakukan Barat menggugah dunia Islam untuk melakukan kritik terhadap karakter Barat dalam memperlakukan HAM itu, sehingga lahirnya berbagai formulasi baru seperti usaha membuat berbagai rancangan undang-undang HAM dalam Islam atau menurut pandangan Islam tidak dapat dibendung, seperti: Deklarasi HAM dan Kewajiban-kewajibannya dalam Islam (diterbitkan oleh Rabithah 'Alam Islamy pada 1979), Penjelasan Islami Universal (diterbitkan oleh Majelis Islam Eropa di London pada 1980), Penjelasan Universal bagi HAM dalam Islam (diterbitkan oleh Majelis Islam Eropa di London pada 1981), Proyek Perjanjian HAM dalam Islam (diajukan pada Konferensi Puncak Organisasi Konferensi Islam [OK] di Thaif pada Januari 1989), dan Proyek Deklarasi HAM dalam Islam (diajukan pada Konferensi ke-5 HAM di Teheran pada Desember 1989) (al-Jabiri, 2003: 98-99).

Di luar pelbagai kenyataan getir tersebut, setiap ide dan perjuangan, tentu tidak semuanya gelap. Tetap ada berbagai kemajuan yang patut dicatat dengan jujur, seperti setiap upaya menegakkan keadilan dan perlindungan terhadap universalitas HAM itu sendiri. Sekalipun di Barat pernah lahir berbagai kebijaksanaan, tetapi pada faktanya masih terdapat tangantangan barbar yang menyelewengkan, khianat atas perjuangan suci memuliakan martabat manusia. Menurut al-Jabiri (2003: 100), proses pengakaran HAM dalam pemikiran Islam kontemporer harus terarah pada upaya menunjukkan universalitas HAM pada masing-masing kebudayaan Barat dan kebudayan Islam, yakni bahwa ia berpijak pada dasar-dasar filsafat yang sama sehingga sampai pada titik terang.

\section{Lahirnya ide hak-hak asasi manusia (HAM)}

Mengenai arti kata "hak" sebenarnya dalam wacana Arab kontemporer merupakan terjemahan dari kata droit (Prancis) dan right(Inggris). Hak (haqq) dalam bahasa Arab merupakan kata yang bermakna ganda karena ia dapat berarti "benar" (vrai/true) sebagai lawan dari "salah" (bätil/faux/ wrong). Kata ḥaqq juga berarti "keyakinan setelah keraguan", dan kata al-ḥaqq juga dipakai untuk menyebut Allah. Interpretasi makna antara "hak" dan "kewajiban" dalam bahasa Arab hanya dibedakan oleh harfjar (sejenis kata penghubung) yang mengikutinya. 
Ungkapan wajaba labu dan wäjibl labu sama artinya dengan ḥaqqa labu dan haqqun labu, sedangkan wajaba 'alaibi dan wäjibun 'alaibi sama artinya dengan ḥaqqa 'alaibi dan ḥaqqun 'alaibi. Dalam kamus Lisān al-'Arab kekhususan makna ini dibaca sebagai: "berhak akan sesuatu: wajib”. Aku menghakkan sesuatu (ahqaqtu al-shay): aku mewajibkannya (anjabtubu). Berhak (istahaqqa): menuntut kewajiban (istanjaba). Berhak dan berkewajiban adalah hampir sama. Jika dikatakan, “dibebankan padamu hak untuk melakukan ini (yubiqqu 'alaika an taf' ala kadha), artinya wajib bagimu dan kamu berhak melakukannya. Haqq adalah bentuk tunggal sedangkan bentuk jamaknya adalah buquq, seolah-seolah dia lebih khusus dan lebih diutamakan. "Dan diberikan bagi yang berhak akan haknya" (wa u'tiya likulli dhi ḥaqq ḥaqqabu), yaitu bagian yang telah ditentukan untuknya dan wajib untuknya (al-Jabiri, 2003: 151-152).

Berdasarkan uraiannya tersebut, al-Jabiri kemudian mengingatkan bahwa seseorang akan melakukan kesalahan besar jika memikirkan HAM melalui apa "yang dipikirkan" dalam pemikiran Eropa modern dan kontemporer, yang memisahkan antara "hak" dan "kewajiban." Jika hal itu dilakukan maka seseorang akan menemukan ruang kosong untuk HAM dalam apa yang dipikirkan oleh tradisi Arab Islam, atau justru terjebak dalam ruang kewajiban. HAM adalah kewajiban-kewajiban bagi manusia untuk melakukan 'pemuliaan". HAM dalam Islam adalah semua urusan materil dan maknawi yang wajib bagi seseorang karena Tuhan memuliakannya dan melebihkannya atas semua makhluk lainnya (al-Jabiri, 2003: 152-153).

Dalam membahas tentang hak-hak individu, Abou El Fadl (2004: 35) menekankan bahwa semua demokrasi konstitusional memberikan perlindungan terhadap kepentingan individu, seperti kebebasan untuk berbicara dan berkumpul, kedudukan yang sama di depan hukum, dan untuk memiliki harta benda, dan jaminan proses hukum di pengadilan. Setiap bentuk penindasan, penyiksaan dan larangan pemenuhan kebutuhan pangan dan perumahan, atau sarana pertahanan hidup lainnya, seperti pekerjaan, merupakan hal yang tidak bisa diterima. Dalam konteks ini, tujuan syariah Islam menurut teori hukum sesungguhnya adalah mewujudkan kesejahteraan manusia (tahqiq masāilị al-íbād). Tradisi hukum Islam menegaskan sejumlah besar pandangan yang memperlihatkan perlindungan terhadap individu (El Fadl, 2004: 35-37). 
Berkaitan dengan rasionalitas penerapan hukum-hukum syariah, al-Jabiri (2001: 168) menjelaskan bahwa sebenarnya upaya membangun rasionalitas hukum syara'berdasarkan "sebab-sebab turunnya ayat" dalam kerangka pertimbangan kemaslahatan akan melapangkan jalan bagi pembangunan rasionalitas lainnya dalam menyikapi kondisi mutakhir perkembangan masyarakat.

Jika kita berbicara tentang asal-usul historis konsepsi HAM sebenarnya bisa dilacak jauh hingga ke masa Yunani dan Roma, yang memiliki kaitan erat dengan doktrin hukum alam pra-modern dari Greek Stoicism (Stoisisme Yunani), sekolah filsafat yang didirikan Zeno di Citium. Doktrin ini antara lain berbunyi bahwa kekuatan raja yang universal mencakup semua ciptaan dan tingkah laku manusia, oleh karenanya harus dinilai berdasarkan-dan sejalan dengan-hukum alam (Arinanto, 2003: 67). Istilah hak-hak asasi manusia (menggantikan istilah natural rights) baru mulai dikenal secara luas semenjak Perang Dunia II bertepatan dengan dibentuknya Perserikatan Bangsa-Bangsa (PBB) pada tahun 1945. Dapat dikatakan bahwa konsep hak-hak asasi manusia berasal dari Magna Charta di Inggris yang berisi prinsip-prinsip Trial by Juri (Peradilan oleh Juri), Habeas Corpus (Surat Perintah Penahan) dan Pengawasan Parlemen atas Hak Pajak. Magna Charta (1215), Habeas Carpus (1670), Undang-undang Hak-hak Asasi (Bill of Rights) (1689), Deklarasi Kemerdekaan Amerika (1776), Deklarasi Hak-hak Manusia dan Warga Negara Prancis (1789), merupakan tombaktombak konstitusional yang menonjol, yang menunjukkan bahwa pelembagaan hak-hak asasi manusia telah melalui proses yang cukup panjang (Vatin, 1995: 114).

Ide-ide HAM memainkan peranan kunci pada akhir abad ke-18 dan awal abad ke-19, dalam perjuangan melawan absolutisme politik. Sebelum abad ke-17, Maududi (1985: 16) menyatakan bahwa orang-orang Barat tidak mempunyai konsep tentang hak-hak asasi manusia dan hak-hak warga negara. Bukti praktis dan pelaksanaan konsep-konsep tersebut baru bisa ditemukan pada akhir abad ke-18, yaitu dalam proklamasi dan konstitusi Amerika Serikat dan Prancis. Sesudah itu, dalam konstitusi berbagai negara mulai tampak adanya rujukan kepada hak-hak asasi manusia meskipun lebih sering hak-hak yang diberikan di atas kertas itu tidak diberikan dalam kehidupan nyata.

Pada pertengahan abad ke-18 itulah, Perserikatan Bangsa-Bangsa (PBB) mengemukakan Universal Declaration of Human Rights dan mensahkan resolusi yang melarang pembunuhan 
besar-besaran atas ras atau kelompok manusia (genocide) dan membuat peraturan untuk mencegah hal tersebut. Dalam perjanjian pendirian PBB itu semua negara bersepakat untuk melakukan langkah-langkah, baik secara bersama-sama maupun terpisah untuk mencapai "universal respect for, and observance of, human rights and fundamental freedoms for all without distinction as to race, sex, language, or religion”. Pada Universal Declaration of Human Rights (1948), perwakilan dari berbagai negara sepakat untuk mendukung hak-hak yang terdapat di dalamnya "as a common standard of achievement for all peoples and all nations". Pada tahun 1976, International Covenant on Economic, Social, and Cultural Rights dan International Covenant on Civil and Political Rights yang disetujui Majelis Umum PBB pada tahun 1976, dinyatakan berlaku (Arinanto, 2003: 78).

Tak dapat dipungkiri bahwa pemikiran para filsuf Eropa memberikan pengaruh besar atas pencetusan HAM, terutama John Locke dalam Second Treatises of Government, Two Treatises of Government, dan Political Writings, serta karya Jean-Jacques Rousseau, The Social Contract, Reveries of the Solitary Walker dan A Discourse on Inequality.

Yang menarik adalah bahwa para filsuf Eropa abad ke-18, seperti Locke dan Rousseau, telah membangun HAM di atas dua hak yang menjadi pokok dari hak-hak yang lain, yaitu hak kebebasan dan hak persamaan. Dua hak pokok tersebut tidak cukup untuk menjadikan HAM yang diserukan oleh para filsuf Eropa itu "universal", sehingga al-Jabiri mendorong agar HAM itu harus bersandar pada otoritas yang berada “di luar" kebudayaan Eropa yang dominan saat itu (al-Jabiri, 2003: 102).

\section{Respon masyarakat dan generasi HAM internasional}

Dari Selatan Afrika ke Uni Soviet hingga ke Amerika Latin dan tempat-tempat lain di dunia, suatu arus perubahan global telah meninggalkan otokrasi politik. Sejak 1989, sejumlah besar negara di pelbagai belahan dunia telah melaksanakan reformasi dan bergerak ke arah kategori kemunculan kembali demokrasi serta memproklamirkan dukungan terhadap HAM internasional. Pada tahun 1989 misalnya, Komite Helsinki di Polandia telah mengumumkan bahwa isu-isu yang berkaitan dengan ideologi akan dikeluarkan dari kurikulum sekolah, dan digantikan dengan nilai-nilai yang terkandung dalam Universal Declaration of Human Rights. Tiga puluh lima negara yang menandatangani Persetujuan Helsinki pada tahun 1975 itu telah menyatakan niat mereka agar pada dekade terakhir dari abad ke-20, sekolah-sekolah dan 
ljtihad, Jurnal Wacana Hukum Islam dan Kemanusiaan, Vol. 12, No. 2, Desember 2012: 217-235

institusi pendidikan didorong untuk mempertimbangkan penyebarluasan nilai-nilai HAM dan kebebasan-kebebasan fundamental dalam kurikulumnya (Arinanto, 2003: 2).

Selain itu, Deklarasi Universal Perserikatan Bangsa-Bangsa (PBB) tentang HAM, Deklarasi Amerika di Bogota tentang Hak-hak dan Kewajiban-kewajiban (1948), Konvensi Hak-hak Asasi Manusia Eropa (1961), dua perjanjian internasional tahun 1966 (satu tentang hak-hak ekonomi, sosial, dan budaya; yang lain tentang hak-hak sipil dan politik), Konferensi Helsinki (1975), Resolusi UNESCO (1975) mengenai sirkulasi informasi dan gagasan-gagasan internasional, semua teks ini memproklamasikan kemenangan internasionalisasi pandangan yang dijabarkan di Barat sepanjang dasawarsa itu (Vatin, 1995: 115).

Arinanto (2003: 4-5) dengan merujuk berbagai sumber mencatat bahwa di tingkat internasional, regional, dan domestik, semenjak pendirian PBB, kuatnya penghormatan terhadap HAM juga ditandai dengan ditetapkannya berbagai instrumen HAM yang antara lain terdiri dari: Pertama, pada tingkat Perserikatan Bangsa-Bangsa (PBB) terdapat: Charter of the United Nations 1945, Universal Declaration of Human Rights 1948, Convention Relating to the Status of Refugees 1954, International Covenant on the Elimination of all Forms of Racial Discrimination (CERD) 1965, International Covenant on Economic, Social, and Cultural Rights (ICESCR) 1966, Convention on the Elimination of All Forms of Discrimination Against Women (CEDAW) 1979, Convention Against Torture and Other Cruel, Inbuman or Degrading Treatment or Punishment (CAT) 1984, Convention on the Rights of the Child (CRD) 1990, Vienna Declaration and Programme of Action (1993). Kedua,pada tingkat regional terdapat: European Convention on Human Rights (ECHR) 1952, American Convention on Human Rights 1969, African (Banjul) Charter on Human and People's Rights 1981, Cairo Declaration on Human Rights in Islam 1990, Bangkok Declaration' 1993, Asian Human Rights Charter 1997. Ketiga, pada tingkat domestik: Declaration of the Rights of Man and Citizen (Declaration des droits de l'homme et du citoyen) 1789 di Perancis, Bill of Rights 1791 di Amerika, Charter of Rights and Fundamental Freedoms 1982 di Kanada, Bill of Rights 1996 di Afrika Selatan, Human Rights Act 1998 di Inggris, dan Undang-Undang Nomor 39 Tahun 1999 tentang Hak Asasi Manusia di Indonesia.

Muatan dan penerapan HAM internasional, sebagaimana tradisi normatif lainnya, tradisi HAM tidak bisa disangkal adalah produk dari masanya dan dinamis sesuai proses sejarah. Ahli hukum Prancis, Karel Vasak diilhami Revolusi Prancis, seperti dikutip Arinanto (2003: 
78-80), membagi HAM dalam tiga generasi.

Generasi Pertama, generasi yang tergolong dalam hak-hak sipil dan politik, terutama yang berasal dari teori-teori kaum reformis pada awal abad ke-17 dan ke-18, yang berkaitan dengan revolusi-revolusi Inggris, Amerika, dan Perancis. Dipengaruhi filsafat politik individualisme liberal dan doktrin sosio ekonomi laissez-faire. Generasi ini meletakkan HAM lebih pada terminologi yang negatif ("bebas dari") daripada terminologi yang positif ("hak dari”). Lebih menghargai ketiadaan intervensi pemerintah dalam pencarian martabat manusia. Termasuk dalam kelompok ini adalah hak-hak sebagaimana dirumuskan dalam Pasal 2-21 Universal Declaration of Human Rights yang telah diadopsi dalam konstitusi lebih dari 175 negara. Mayoritas deklarasi internasional dan kovenan-kovenan yang ditetapkan sejak Perang Dunia II dipandang sebagai kemenangan individualisme Hobbes dan Locke terhadap statisme Hegel.

Generasi Kedua, generasi yang tergolong dalam hak-hak ekonomi, sosial, dan budaya, yang berakar secara utama pada tradisi yang membayang-bayangi di antara Saint-Simonians pada awal abad ke-19 di Perancis dan secara beragam diperkenalkan melalui perjuangan revolusioner dan gerakan-gerakan kesejahteraan setelah itu. Dalam bagian yang luas, ia merupakan respon terhadap pelanggaran-pelanggaran dan penyelewengan-penyelewengan dari perkembangan kapitalis dan menggarisbawahinya; tanpa kritik yang esensial, konsepsi kebebasan individual yang mentoleransi bahkan melegitimasi eksploitasi kelas pekerja dan masyarakat kolonial.

Generasi Ketiga, generasi yang mencakup hak-hak solidaritas (solidarity rights) yang merupakan rekonseptualisasi dari kedua generasi HAM sebelumnya. Ia dapat dipahami sebagai suatu produk—sekalipun sebagian masih dalam proses pembentukan_-dari kebangkitan dan kejatuhan negara-bangsa dalam paruh kedua dari abad ke-20. Tercantum dalam Pasal 28 Universal Declaration of Human Rights, yang tampak mencakup enam hak sekaligus. Tiga dari mereka merefleksikan bangkitnya nasionalisme Dunia Ketiga dan keinginannya untuk mendistribusikan kembali kekuatan, kekayaan, dan nilai-nilai lain yang penting. Lahirnya generasi ketiga, dalam sekup yang luas, sekaligus menandai kritik terhadap ide dan penerapan HAM itu sendiri. Kritik terhadap PBB, kritik terhadap dominasi Barat yang terutama berkaitan dengan penyelewengan HAM (Arinanto, 2003: 78-80). 
ljtihad, Jurnal Wacana Hukum Islam dan Kemanusiaan, Vol. 12, No. 2, Desember 2012: 217-235

\section{Makna HAM dalam Islam}

Konsep-konsep HAM berasal dari Magna Charta di Inggris. Kita tahu Magna Charta muncul sekitar enam ratus tahun setelah lahirnya Islam. Tidak mungkin dibantah, periode Muhammad, dan secara khusus merujuk kitab suci al-Qur'an dan hadis, ajaran tentang hak-hak asasi manusia, telah lama ada, telah lama dilahirkan. Sekalipun sah mengatakan ia berbeda dengan Universal Declaration of Human Rights, bagaimanapun juga seruan tentang kebebasan, kemanusiaan, persaudaraan dan keadilan telah digemakan sepanjang zaman di mana Islam hidup. Sebuah hadis mengatakan: "Cintailah orang lain sebagaimana engkau mencintai dirimu". Persoalannya adalah kondisi sosiologis (zaman) di mana Islam tumbuh dan berkembang atau sebaliknya mengalami kemunduran-kemunduran. Salah satu langkah besar yang ditempuh pada periode Muhammad saw. yakni menghapus perbudakan yang dalam konteks luas agama-agama kuno pun menyebut tindakan membebaskan budak-budak sebagai tindakan baik, tetapi agama-agama kuno itu tidak menghilangkan lembaga perbudakan. Kita tahu persis, tangan Tuhan memang tidak hadir langsung, lalu tertangkap oleh indera kita, bagaimana Dia mengatur dan mengontrol penerapan hak-hak asasi manusia itu.

Harun Nasution (1995: vi-vii) mengatakan bahwa falsafah dasar dari HAM terdapat dalam agama tauhid, agama yang mengajarkan kemahaesaan Tuhan, yang ada hanya satu Pencipta bagi alam semesta, là ilāha illā Allāh. Dalam tauhid, terkandung ide persamaan dan persaudaraan seluruh manusia, bahkan mencakup ide persamaan dan persatuan semua makhluk, benda tak bernyawa, tumbuh-tumbuhan, hewan dan manusia. Tegasnya, dalam agama tauhid terdapat pula ide perikemakhlukan di samping ide perikemanusiaan.

Dalam Islam, sebagaimana dikatakan oleh Abul A’la Maududi (1985: 17-18) bahwa seluruh hak asasi adalah mutlak pemberian Allah, bukan pemberian seorang raja atau lembaga legislatif. Hak-hak yang diberikan oleh raja-raja dan lembaga-lembaga legislatif apalagi para diktator bisa saja dicabut kembali bila dikehendaki, tetapi karena dalam Islam hak-hak asasi manusia diberikan oleh Allah, maka tak satu pun lembaga atau negara di dunia yang berhak mengubah atau mencabutnya. Sebuah ayat dalam al-Qur'an dengan lantang dan gamblang menyeru, "Barangsiapa yang tidak membuat ketetapan berdasarkan apa yang telah diturunkan Allah, maka merek. a adalah orang-orang kafir" (QS. Al-Mà'idah: 44). 
Maududi (1985: 18) menyimpulkan bahwa piagam-piagam pernyataan dan resolusi PBB, jelas tidak dapat dibandingkan dengan hak-hak yang telah diberikan dan dijamin Allah. Sebab piagam-piagam, pernyataan-pernyataan atau resolusi PBB tidak diberlakukan untuk seluruh manusia. Sedangkan HAM dalam Islam adalah bagian dari ajaran Islam. Setiap manusia atau pemerintah yang mengaku sebagai Muslim harus rela menerima, mengakui dan memberlakukan hak-hak tersebut.

Pandangan dunia Barat yang antroposentris_manusia berada di pusat dan ia harus dianggap sebagai tolak ukur segala sesuatu_-ia memiliki hak-hak asasi dengan alasan dan kenyataan bahwa ia merupakan bagian pusat dari alam. Pandangan teologi Islam, karena Allah merupakan pusat, manusia hanya mempunyai kewajiban terhadap Tuhan, dan manusia pada gilirannya memperoleh hak mereka dari kewajiban orang-orang yang beriman terhadap Tuhan. Inilah perbedaan yang paling mendasar menyangkut terminologi HAM dalam Islam dan HAM yang bertolak dari Barat.

Sejalan dengan ajaran kebebasan manusia dalam Islam, al-Qur'an mengajarkan (tidak ada paksaan dalam agama), là ikrāha fi al-din (QS. Al-Baqarah: 256). Allah swt. berfirman dalam QS. Yünus: 99: Afa anta tukrih al-nās ḥatta yakūnū mu'minīn (apakah engkau paksa manusia sehingga menjadi mukmin?) Allah swt. mengatakan kepada Nabi saw. dalam QS. al-Shüra: 48: In alaike a illa al-balägh (kewajibanmu menyampaikan). Dalam ayat lain Allah swt. berfirman: "beri ingatlah, engkau hanya pemberi ingat, bukanlah engkau yang berkuasa atas mereka" (QS. al-Ghasyiah: 21-22). Prinsip pergaulan antara pemeluk agama yang berbeda dalam Islam adalah lakum dinukum wa liya din, (berpeganglah engkau pada agamamu dan aku berpegang pada agamaku) (QS. al-Käfirūn: 6). Sekali lagi, bukankah tidak bisa dibantah, Islam telah berbicara tentang kebebasan, pluralitas dan toleransi sejak berabad-abad yang lampau.

Dari ajaran dasar persamaan, persaudaraan dan kebebasan manusia itu timbul kebebasankebebasan manusia. Di samping kebebasan dari perbudakan dan kebebasan beragama juga kebebasan dari kekurangan, kebebasan dari rasa takut, kebebasan mengeluarkan pendapat, kebebasan bergerak, kebebasan dari penganiayaan dan lain-lain. Dari situ pula timbul hakhak asasi manusia seperti hak hidup, hak memiliki harta, hak mengecap pendidikan, hak berbicara, hak berpikir, hak mendapat pekerjaan, hak memperoleh keadilan, hak berkeluarga, 
dan lain-lain (Nasution, 1985: xi-xii). Kemaslahatan manusia hari ini tidak lagi terbatas pada pemeliharaan agama, jiwa, akal, keturunan dan harta, melainkan mencakup juga: hak bagi kebebasan mengemukakan pendapat dan afiliasi politik, hak memilih para penguasa dan mengganti mereka, hak mendapatkan kerja, hak pendidikan, hak pengobatan dan sebagainya (al-Jabiri, 2001: 181).

Sementara Maududi (1985: 21-82) lebih jauh mengetengahkan hak-hak asasi manusia dalam Islam ke dalam dua klasifikasi besar, yakni hak-hak asasi manusia (yang diperuntukkan bagi seluruh umat) dan hak-hak warga negara dalam negara Islam. Hak-hak warga negara dalam negara Islam, mencakup: keamanan hidup dan harta benda, perlindungan kehormatan, kehormatan dan keamanan kehidupan pribadi, keamanan kebebasan pribadi, hak untuk memprotes, kebebasan mengemukakan pendapat, kebebasan berserikat, kebebasan hidup nurani dan keyakinan, kebebasan keyakinan beragama, perlindungan dari penahanan semenamena, hak atas kebutuhan hidup yang pokok, persamaan di depan hukum, penguasa tidak berada di atas hukum, hak untuk menghindari dosa, dan hak berpartisipasi dalam pemerintahan. Sedangkan hak-hak asasi manusia, hak bagi manusia sebagai manusia, dari negeri manapun, beriman maupun tidak, bagaimanapun ia memiliki beberapa hak asasi semata-mata karena ia seorang manusia, yang harus diakui oleh setiap Muslim, dan wajib dipenuhinya.

1. Hak untuk hidup. Ini adalah hak yang paling dasar dari seluruh hak asasi manusia. Dalam keadaan bagaimanapun, tak seorang pun yang mempunyai hak sendiri untuk mencabut nyawa manusia sebagai pembalasan atau hukuman bagi penyebaran kerusakan di muka bumi. Masalah ini hanya bisa diputuskan oleh sidang pengadilan yang kompeten. Perang antar negara juga hanya bisa diputuskan pemerintah yang berwenang. Al-Qur'an menyatakan: "Barangsiapa membunuh manusia bukan karena ia telah membunuh manusia lain, atau bukan karena ia membuat kerusakan di bumi, maka seakan-akan ia telah membunuh seluruh manusia” (QS. al-Mā'idah: 32).

2. Hak untuk hidup aman. Manusia sudah semestinya mengupayakan keselamatan hidupnya juga keselamatan hidup orang lain: memberikan pertolongan, perawatan dan segala bentuk kepedulian terhadap orang yang membutuhkan. "Dan barangsiapa yang menyelamatkan bidup seorang manusia, maka seakan-akan ia telah menyelamatkan hidup seluruh umat manusia" (QS. alMāidah: 32). 
3. Penghargaan terhadap kehormatan wanita. Kesucian wanita harus dihormati dan dilindungi dalam setiap keadaan, tanpa memandang bangsa, asal-usul dan agama. Hubungan seks bebas adalah terlarang. "Janganlab engkau mendekati zina”"(QS. al-Isrā': 32).

4. Hak atas standar kehidupan minimal. Siapa pun yang meminta pertolongan dan siapa pun yang membutuhkan tetapi terhalang dari meminta-minta, mempunyai hak dalam harta benda dan kekayaan kaum Muslimin, tanpa memandang ras, bangsa dan agama. "Dan pada harta mereka ada hak bagi orang-orang miskin yang meminta, dan orang-orang miskin yang terhalang dari meminta-minta” (QS. al-Dhāriyāt: 12).

5. Hak kemerdekaan individu. Islam melarang praktek menangkap seorang manusia yang merdeka untuk dijadikan budak atau dijual sebagai budak. "Di hari kiamat nanti, ada tiga jenis manusia yang akan kutuntut secara pribadi; salah satu di antaranya adalah orang yang memperbudak manusia merdeka, kemudian menjualnya, dan memakan uang hasil penjualannya itu" (HR. Bukhari dan Ibnu Majah).

6. Hak memperoleh keadilan. Kaum Muslimin dituntut tidak hanya untuk berbuat adil terhadap manusia pada umumnya, tetapi secara keseluruhan bahkan terhadap musuhmusuh mereka. "Dan janganlah sekali-kali kebencianmu pada orang lain mendorongmu untuk bertindak melampaui batas" (QS. al-Mà'idah: 2). "Dan janganlah sekali-kali kebencianmu terhadap suatu kaum mendorongmu untuk berlaku tidak adil. Berlaku adillah, karena adil itu lebih dekat kepada taqwa” (QS. al-Mà'idah: 8).

7. Persamaan manusia. Semua manusia adalah bersaudara. Islam tidak hanya mengakui persamaan yang mutlak di antara umat manusia, tanpa memandang segala perbedaan, tetapi juga menjadikannya sebagai prinsip yang sangat penting. "Wahai umat manusia, sesungguhnya Kami telah menciptakanmu dari sepasang lelaki dan wanita, dan menciptakan kamu berbangsa-bangsa dan bersuku-suku, agar kamu saling kenal-mengenal” (QS. al-Hujurāt: 13).

"Orang-orang Arab tidak mempunyai kelebihan terhadap bangsa 'Ajam (bukan-Arab), tidak pula bangsa 'Ajam mempunyai kelebihan atas bangsa Arab. Bangsa-bangsa kulit putih tidake mempunyai kelebihan atas bangsa kulit hitam, bangsa kulit hitam juga tidak punya kelebihan atas bangsa kulit putih. Kamu adalah anak cucu Adam, dan Adam diciptakan dari tanab” (HR. Baihaqi dan Bazzas). 
ljtihad, Jurnal Wacana Hukum Islam dan Kemanusiaan, Vol. 12, No. 2, Desember 2012: 217-235

\section{Mendekatkan filsafat HAM Barat dengan konsep Islam}

Bagi Hassan Hanafi (2001: 93-94) Islam adalah prinsip universal rasional, sebuah prinsip kesatuan atau transendensi di mana akal manusia pada hakikatnya dapat menerima universalitas. Transendensi merupakan norma aksiologis, standar perilaku dan kode etik universal, parameter nilai dan dasar kehidupan moral. Bagi Hanafi, secara garis besar esensi Islam adalah afiliasi terhadap prinsip universal dan manifestasi kebaikan, sehingga dapat dikatakan bahwa Islam sebagai etika global untuk solidaritas kemanusiaan, sedangkan prinsip universalnya adalah basis teoretis bagi etika global (Hanafi, 2001: 100).

Al-Jabiri (2003: 103) mengemukakan bahwa agama tidaklah menjadi otoritas "universal" yang dijadikan dasar oleh para filsuf Eropa abad ke-18 bagi universalitas HAM yang mereka serukan, sebaliknya mereka dengan sengaja membangun otoritas rasional yang berdiri sendiri dan melampaui Gereja. Ia adalah otoritas yang terdiri dari tiga hipotesis utama, yaitu pandangan tentang persamaan antara sistem alam dan sistem akal, hipotesis mengenai apa yang mereka namakan "kondisi alamiah", dan ide tentang "kontrak sosial."

Para filsuf Eropa telah memfungsionalisasikan prinsip atau hipotesis "kesamaan antara sistem alam dengan sistem akal" dalam rangka menjadikan akal sebagai otoritas utama. Apa yang tampaknya rasional, yakni dapat diterima oleh akal, adalah alamiah, yaitu sesuai—atau mau tidak mau sesuai—dengan alam. Tugas akal adalah menyingkap sisi alamiah, yakni sisi rasional, di segala bidang dan melempar ke belakang segala sesuatu yang tidak alamiah, yakni semua tambahan yang terakumulasi dalam konsep manusia terhadap segala sesuatu sebagai akibat dari taklid, satu akibat karena tidak mempergunakan akal. Manusia adalah sama dan bebas dalam hubungan satu sama lain karena hak manusia akan kebebasan dan persamaan merupakan hak alamiah, bagian dari kerja alam. Dari sinilah berpangkal upaya penyamaan antara pengertian "HAM" dan "Hak-hak Alamiah": HAM adalah hak-hak alamiah manusia (Al-Jabiri, 2003: 104).

Para filsuf hukum dan politik modern Eropa abad ke-17 dan 18 menghipotesiskan "kondisi alamiah" bagi manusia. John Locke (1632-1704) adalah filsuf Inggris yang paling banyak melakukan upaya untuk menjadikan hipotesis ini sebagai otoritas yang mendasari "universalitas" HAM (al-Jabiri, 2003: 105). Menurut Locke, kondisi alamiah (state of nature) adalah suatu keadaan harmonis yang ditandai dengan persamaan hak dan kebebasan semua 
manusia. Dalam bukunya Two Treatises of Government ia menulis bahwa kondisi alamiah merupakan a state of peace, good will, mutual assistance, and preservation (Wattimena, 2007: 16).

Jean-Jacques Rousseau (1778-1712), seorang filsuf Perancis, mengemukakan hipotesis "kontrak sosial" yang mencoba menafsirkan cara transisi dari "kondisi alamiah" menuju kondisi sipil. Hipotesis "kontrak sosial” Rousseau menetapkan tentang cara transisi dari "kondisi alamiah" menuju "kondisi sipil", sambil tetap melaksanakan hak-hak manusia yang alamiah itu (Al-Jabiri, 2003: 107). Rousseau menyatakan bahwa manusia dilahirkan bebas, tetapi di mana-mana ia terbelenggu. Dalam bukunya The Social Contractia ingin menemukan suatu bentuk masyarakat yang legitim, di mana manusia hanya tunduk pada dirinya sendiri dan tetap bebas (Wattimena, 2007: 51).

Dapat dipahami bahwa para filsuf Eropa abad ke-18 berusaha membangun dasar bagi "HAM" dalam pemikiran Eropa Modern, melalui fungsionalisasi tiga hipotesis atau "dasardasar teoretis", yaitu: (1) "menyamakan sistem alam dengan sistem akal"; (2) "kondisi alamiah"; dan (3) "kontrak sosial". Menanggapi dasar-dasar teoretis yang dicetuskan oleh para filsuf Barat tersebut, al-Jabiri mencoba mendekatkan tiga hipotesis tersebut dengan konsep-konsep yang ada dalam Islam, sebagai berikut:

Dapat dibaca dengan mudah dalam wacana dakwah Islam, khususnya dalam al-Qur'an. Al-Qur'an berulang kali mengajak kita untuk merenungkan sistem alam dan menarik kesimpulan darinya. Al-Qur'an seringkali mengakhiri ajakannya itu dengan ungkapanungkapan yang mengisyaratkan bahwa sistem alam pada dasarnya adalah sistem akal itu sendiri.

"Sesungguhnya dalam penciptaan langit dan bumi dan pergantian siang dan malam, pada kapal yang berlayar di laut yang membawa manfaat bagi manusia, dan apa yang diturunkan Allah dari langit, yang dengannya Dia hidupkan bumi setelah ia mati, pada makbluk-mak.khluk melata yang ditebarkanNya di antara langit dan bumi, semua itu adalah tanda-tanda bagi orang-orangyang berakal" (QS. al-Baqarah: 164).

Di sini, sistem alam (yakni langit dan bumi, pergantian siang dan malam) merupakan tanda-tanda yang dapat ditangkap oleh akal signifikansinya.

Islam adalah agama "fitrah", dan fitrah dalam wacana al-Qur'an adalah satu konsep yang hampir sama dengan konsep "kondisi alamiah”, sebagaimana disebutkan al-Quran, 
ljtihad, Jurnal Wacana Hukum Islam dan Kemanusiaan, Vol. 12, No. 2, Desember 2012: 217-235

"badapkanlah wajahmu pada agama yang hanif, yaitu fitrah Allah yang di atasnya Allah menciptakan manusia. Tidak ada perubahan dalam ciptaan Allah. Itulah agama yang lurus, namun kebanyakan manusia tidak mengetahui" (QS. al-Rūm: 30). Kondisi fitrah dekat dengan "kondisi alamiah". "Dulu umat manusia tidak lain hanya satu, kemudian mereka berselisib” (QS. Yūnus: 19), "dulu manusia itu adalah umatyang satu, kemudian Allab mengutus nabi untuk memberi kabar gembira dan peringatan" (QS. al-Baqarah: 213). "Setiap anak dilabirkan dalam keadaan fitrah maka kedua orang tuanyalah yang menjadikannya yahudi, nasrani, ataupun majusi”. Sebenarnya para filsuf Eropa abad ke-18 sebenarnya dengan berlindung di bawah pemikiran "kondisi alamiah" dan hipotesis "kontrak sosial", telah membangun dasar bagi satu revolusi, yaitu revolusi yang dikenal dengan revolusi kaum borjuis, revolusi kelas menengah. Adapun ajakan Islam, maka dengan upayanya memfungsionalisasikan konsep fitrah, ia telah membangun dasar bagi revolusi "kaum yang lemah" melawan "kaum yang sombong", revolusi "tauhid" melawan "syirik", revolusi ketergantungan hanya kepada Allah dan bebas dari segala kekuasaan dan ikatan lainnya.

Kontrak sosial dekat dengan perjanjian (mīthāq) atau musyawarah (shürā dalam al-Qur'an. "Dan ingatlah ketik.a Allah mengambil dari sulbi anak cucu Adam semua keturunan mereka dan dia meminta mereka untuk menyaksikan, bukankah aku ini Tuhanmu? Mereka pun menjawab, benar, kami bersaksi demikian" (QS. al-A’raf: 72). Musyawarah adalah kontrak yang membentuk satu masyarakat: "dan urusan mereka, mereka bermusyawarah" (QS. al-Shūrā: 38), dan mengatur hubungan antara manusia dan Negara: "dan bermusyawarablah kamu dalam masalab itu” (QS. Āli 'Imrān: 159) (al-Jabiri, 2003: 110-117).

Dengan upaya pendekatan (kondisi alamiah-kondisi fitrah, kontrak sosial-musyawarah), al-Jabiri (2003: 119) menyangkal dirinya ingin mengatakan bahwa Islam lebih dahulu mengemukakan ini dan itu, melainkan hanyalah membangkitkan perhatian kita bahwa klaim para filsuf Eropa baik Locke maupun Rousseau tentang “universalitas” HAM, yaitu hak akan kebebasan dan persamaan bukanlah khas Eropa.

\section{Penutup}

Al-Jabiri tetap berusaha meletakkan HAM dalam konteks sejarah pemikiran Eropa dan menjaga agar tradisi Islam tetap dapat selaras dengan HAM. Seperti yang ia tegaskan bahwa 
HAM lahir dari filsafat alamiah yang dimulai dari fisika Newton, kemudian diolah dalam filsafat Locke dan Rousseau. HAM lahir sesungguhnya merupakan upaya untuk melawan segala bentuk penindasan oleh manusia atas manusia lainnya. HAM adalah konsep yang bertitik tolak pada hakikat alamiah manusia dan karenanya ia bersifat universal. Hakikat alamiah dalam filsafat Barat itulah kemudian yang dinamakan dengan fitrah dalam Islam. Usaha strategis intelektual yang dilakukan oleh al-Jabiri dalam mendudukkan HAM dalam konteks pemikiran Barat dan Islam secara terbuka dipengaruhi secara signifikan oleh filsuf Muslim yang paling ia kagumi yaitu Ibnu Rusyd yang secara mengagumkan mampu mencanangkan kembali watak rasional dari pemikiran Islam dan berhasil meletakkan hubungan Islam dan filsafat Yunani dalam mekanisme dan historisitasnya masing-masing.

Contoh konkret tentang kontrak sosial dalam Islam ialah Piagam Madinah. Muqtader Khan menilai bahwa Piagam Madinah sebagai sebuah kontrak sosial, karena menyajikan sebuah contoh historis yang sangat baik tentang dua konstruksi teoretis yang membentuk teori demokrasi modern—konstitusi dan kontrak sosial—dan oleh karena itu memiliki nilai yang sangat tinggi untuk membangun teori negara Islam. Secara alamiah, manusia memiliki kebebasan dan tidak wajib mengikuti aturan atau hukum apa pun. Manusia pada dasarnya adalah individu-individu yang memiliki kedaulatan. Melalui kontrak sosial, mereka menyerahkan kedaulatan individual itu kepada kelompok kolektif dan menciptakan sebuah negara. Negara kemudian berperan sebagai sebuah agen dari rakyat berdaulat. Konstitusi merupakan perwujudan yang gamblang dari kontrak sosial dan berperan sebagai landasan hukum bagi sebauh sistem politik. Perjanjian Madinah, yang memiliki fungsi ganda, yaitu sebagai kontrak sosial dan konstitusi, merupakan bentuk legitimasi Muhammad saw untuk memerintah Madinah. Perjanjian Madinah tidak memaksakan syariah kepada siapa pun, dan tidak ada hukum tertentu yang dipandang ada sebelum adanya perjanjian tersebut. Risalah Muhammad saw atau pesan-pesan Tuhan dalam al-Qur'an sama sekali tidak menghujat prinsip-prinsip perjanjian tersebut, karena menyuarakan nilai-nilai Islam seperti kesetaraan, musyawarah, dan konsensus (Khan, 2004: 70-72).

Ketika berbicara tentang kewajiban pemerintah dan kewajiban individu, Locke dalam The Second Treatise selalu berbicara dengan kosakata consensus sehingga konsep itu dapat disamakan dengan "apa yang seharusnya dilakukan oleh individu" atau "apa yang secara 
moral benar." Ia menggunakan istilah konsensus dalam arti teleologis tentang kewajiban politis. Landasan moral bagi pemikiran politiknya adalah perlindungan terhadap hak-hak individu (Wattimena, 2007: 23-24). Sebenarnya dalam pemikiran negara hukum klasik nama Hobbes tak dapat dilepaskan begitu saja, dalam bukunya Man and Citizen ia berpendapat bahwa individu memiliki kewajiban moral yang mutlak dan niscaya untuk patuh kepada otoritas politik.

Akhirnya, baik Abed al-Jabiri, Hassan Hanafi maupun Abul A’la Maududi dengan jelas telah meletakkan pondasi pemikiran Islam tentang HAM yang dapat dipahami sebagai upaya rasional untuk menjaga universalitas HAM terbebas dari cengkeraman dominasi sepihak Barat yang cenderung eksklusif, sebuah usaha rasional untuk mengatasi paradoks HAM yang seringkali justru bermakna berlawanan bagi perwujudan hidup adil dan bebas. Dalam kaitan ini, al-Jabiri, Hanafi dan Maududi dapat menunjukkan kerangka teoretik Islam tentang universalitas hak-hak individu sebagaimana telah diteoretisasikan oleh Locke, Rousseau dan Hobbes.

\section{Daftar pustaka}

Arinanto, Satya. Hak Asasi Manusia dalam Transisi Politik di Indonesia. Jakarta: Pusat Studi Hukum Tata Negara Fakultas Hukum Universitas Indonesia (UI), 2003.

El Fadl, Khaled Abou. Islam dan Tantangan Demokrasi. terj. G.A. Rahmani dan Ruslani. Jakarta: Ufuk, 2004.

Falk, Richard, "HAM dan Pola-pola Dominasi di Barat: Kekacauan Cara Pandang, Praktik yang Kacau" dalam Candra Muzaffar, dkk. Human's Wrong: Rekor Buruk Dominasi Barat atas HAM. Yogyakarta: Pilar Media, 2007.

Hanafi, Hassan. Agama, Kekerasan, dan Islam Kontemporer. Yogyakarta: Jendela, 2001. Al-Jabiri, Muhammad Abed. Al-Dimūqratiyyah wa Huqūq al-Insān (Demokrasi dan HAM). Syura: Tradisi, Partikularitas, Universalitas. terj. Mujiburrahman. Yogyakarta: LKIS, 2003. Al-Jabiri, Muhammad Abed. Agama, Negara dan Penerapan Syariah. terj. Mujiburrahman. Yogyakarta: Fajar Pustaka Baru, 2001. 
Khan, Muqtader, "Prioritas Politik" dalam Khaled Abou El Fadl. Islam dan Tantangan Demokrasi. terj. G.A. Rahmani dan Ruslani. Jakarta: Ufuk, 2004.

Maududi, Abul A'la. Hak Asasi Manusia dalam Islam. terj. Achmad Nashir Budiman. Bandung: Pustaka, 1985.

Teng, Fan Yew, “Kejahatan atas Kemanusiaan: Rapor Merah Barat tentang HAM” dalam Candra Muzaffar, dkk. Human's Wrong: Rekor Buruk Dominasi Barat atas HAM. Yogyakarta: Pilar Media, 2007.

Vatin, Jean Claude, "HAM dalam Islam” dalam Sidney Hook, dkk. Hak Asasi Manusia dalam Islam. Jakarta: YOI, 1995.

Wattimena, Reza A.A. Melampani Negara Hukum Klasik: Locke, Rousseau dan Habermas. Yogyakarta: Kanisius, 2007. 